\title{
Jurist-Diction
}

Volume 4 No. 1, Januari 2021

\section{Tanggung Jawab Korporasi Atas Dampak Pencemaran Lingkungan Akibat Aktivitas Pembangkit Listrik Tenaga Panas Bumi}

\author{
Bagas Adam Arifin \\ bagasadam58@gmail.com \\ Universitas Airlangga
}

\author{
How to cite: \\ Bagas Adam Arifin, 'Tanggung \\ Jawab Korporasi Atas Dampak \\ Pencemaran Lingkungan \\ Akibat Aktivitas Pembangkit \\ Listrik Tenaga Panas Bumi' \\ (2021) Vol. 4 No. 1 Jurist- \\ Diction.

\section{Histori artikel:} \\ Submit 1 Oktober 2020; \\ Diterima 12 November 2020; \\ Diterbitkan 5 Januari 2021. \\ DOI: \\ 10.20473/jd.v4i1.24292 \\ p-ISSN: 2721-8392 \\ e-ISSN: $2655-8297$
}

\section{Abstract}

This thesis aims to determine the corporate responsibility as a manager of Geothermal Power Plants for the impact of pollution due to the activities of the Geothermal Power Plant and legal protection obtained by the public for the impact of pollution from the activities of the Geothermal Power Plant. The research method used is the normaptive method through a law approach and conceptual approach. In the exploration activities of Geothermal Power Plants, it is known that it can cause pollution and / or environmental damage such as landslides resulting from exploration that fall into the upper reaches of the river and pollute the environment along the river channel which impacts on the community. In addition, legal protection for the community must be upheld so that community rights are not violated due to geothermal exploitation that violates the provisions.

Keywords: Geothermal; Responsibility; Corporations; Environment; Legal Protection.

\section{Abstrak}

Penelitian ini bertujuan untuk mengetahui tanggung jawab korporasi sebagai pengelola Pembangkit Listrik Tenaga Panas Bumi atas dampak pencemaran akibat aktivitas dari Pembangkit Listrik Tenaga Panas Bumi dan perlindungan hukum yang didapat masyarakat atas dampak pencemaran dari aktivitas Pembangkit Listirk Tenaga Panas Bumi. Metode penelitian yang digunakan yaitu metode yuridis normatif dengan melalui pendekatan undang-undang. Dalam aktivitas eksplorasi Pembangkit Listrik Tenaga Panas Bumi diketahui dapat menyebabkan pencemaran dan/atau kerusakan lingkungan seperti longsoran tanah hasil dari eksplorasi yang jatuh ke hulu sungai dan mencemari lingkungan disepanjang alur sungai yang berdampak pada masyarakat. Selain itu, perlindungan hukum bagi masyarakat harus ditegakkan agar hak-hak masyarakat tidak dilanggar akibat pengusahaan panas bumi yang menyalahi ketentuan.

Kata Kunci: Panas Bumi; Tanggung Jawab; Korporasi; Lingkungan; Perlindungan Hukum. 


\section{Pendahuluan}

Indonesia adalah salah satu negara yang memiliki banyak sumber daya alam yang melimpah yang terdiri atas sumber daya alam yang dapat diperbarui maupun yang tidak dapat diperbarui, sumber daya alam hayati dan non hayati. Bahan galian tersebut dapat berupa emas, perak, tembaga, nikel, batubara, minyak dan gas bumi. Bahan galian tersebut dikuasai oleh negara. ${ }^{1}$ Hal tersebut sebagaimana tercantum didalam Pasal 33 Undang-Undang Dasar Negara Republik Indonesia Tahun 1945 dan Pasal 2 Undang-Undang Pokok Agraria Negara Republik Indonesia Tahun 1945 yang menyatakan bahwa bumi, air beserta kekayaan alam yang terkandung dikuasai seluruhnya oleh negara yang digunakan sebesar-besarnya untuk kemakmuran rakyat. Dalam hal ini, dikuasai oleh negara memiliki makna Hak Penguasaan Negara atas aset kekayaan alam. Negara berdaulat mutlak atas penguasaan kekayaan sumber daya alam. Hak kepemilikan yang sah atas kekayaan alam adalah milik rakyat Indonesia. Kedua makna tersebut adalah satu kesatuan yang tidak dapat dipisahkan. Hak penguasaan negara sebagai instrumen sedangkan kemakmuran rakyat yang sebesar-besarnya adalah tujuan akhir pengelolaan alam. ${ }^{2}$

Kekayaan sumber daya alam yang ada di Indonesia ini dapat dimanfaatkan untuk kebutuhan serta kesejahteraan seluruh rakyat Indonesia. Sebagaimana yang tertuang didalam Pasal 33 ayat (3) UUD NRI 1945 dimana bumi, air beserta isinya dikuasai seluruhnya oleh negara dan digunakan untuk kemakmuran rakyat. ${ }^{3}$ Peran pemerintah didalam sektor pertambangan menjadi sangat penting berkaitan dengan hak penguasaan yang dimilikinya untuk mengelola kekayaan sumber daya alam sehingga dapat dinikmati oleh seluruh rakyat Indonesia yang bertujuan untuk terciptanya masyarakat yang adil dan makmur.

Dalam pelaksanaan kegiatan pemanfaatan panas bumi juga menimbulkan dampak positif dan negatif sehingga dengan adanya peraturan yang mengatur tentang pelaksanaan kegiatan pemanfaatan Panas Bumi diharapkan salah satunya dapat

\footnotetext{
${ }^{1}$ H.Salim HS, Hukum Pertambangan di Indonesia (Raja Grafindo Persada 2007).[1].

2 Adrian Sutedi, Hukum Pertambangan (Sinar Grafika 2007).[24].

3 Nandang Sudrajat, Teori dan Praktik Pertambangan Indonesia (Pustaka Yustisia 2013).[1].
} 
meningkatkan pemanfaatan energi terbarukan berbentuk panas bumi yang berguna untuk memenuhi kebutuhan energi nasional dan sebagai pengendali dalam kegiatan pemanfaatan panas bumi yang mendukung pembangunan yang berkelanjutan. Salah satu pemanfaatan panas bumi tersebut adalah dengan dibangunnya Pembangkit Listrik Tenaga Panas Bumi yang memanfaatkan panas bumi untuk menghasilkan listrik. Di Indonesia telah dibangun beberapa Pembangkit Listrik Tenaga Panas Bumi untuk menunjang kebutuhan energi listrik nasional. Panas bumi merupakan salah satu energi alternatif yang dapat diperbarui. Panas bumi merupakan sumber energi panas yang ada didalam air panas, uap air, batuan beserta mineral dan gas lainnya yang secara genetik tidak bisa dipisahkan menurut Pasal 1 Undang-Undang Panas Bumi. Berbeda dengan sumber energi berupa batubara maupun minyak bumi yang berasal dari sisa bahan organik, energi panas bumi terjadi karena pertemuan magma yaitu panas dalam "perut bumi" dengan air. ${ }^{4}$

Panas bumi merupakan sumber daya alam yang dapat diperbarui. Energi panas dikelompokkan sebagai sumber energi yang dapat diperbaharui karena sumber energi ini berasal dari panas bumi yang selalu diproduksi oleh bumi selama bumi berotasi. Energi panas bumi mempunyai potensi yang besar serta memiliki peranan yang vital sebagai salah satu sumber energi pilihan dalam keanekaragaman energi nasional guna menunjang pembangunan nasional yang berkelanjutan. ${ }^{5}$

Pembangunan menjadi salah satu upaya manusia untuk mencapai kehidupan yang lebih baik. Esensi dari pembangunan yaitu guna untuk mencapai kehidupan yang lebih baik dari hari ini. Sektor pemanfaatan panas bumi menjadi salah satu cara guna mempercepat terlaksananya pembangunan ekonomi nasional di Indonesia. Kegiatan pemanfaatan panas bumi dapat dilakukan secara langsung dan pemanfaatan secara tidak langsung. Pemanfaatan panas bumi secara tidak langsung diatur dalam Peraturan Pemerintah Republik Indonesia Nomor 7 Tahun 2017 Tentang Panas

\footnotetext{
${ }^{4}$ Abdul Kadir, Energi: Sumber Daya, Inovasi, Tenaga Listrik, dan Potensi Ekonomi (Penerbit Universitas Indonesia 1995).[12].

${ }^{5}$ M Hafiz Alfath, 'Listrik Dari Panas Bumi' (2010) Vol. 40 No. 3 Jurnal Hukum dan Pembangunan Universitas Indonesia.[5].
} 
Bumi Untuk Pemanfaatan Tidak Langsung. Kegiatan pemanfaatan panas bumi baik secara langsung maupun tidak langsung memiliki memiliki banyak manfaat positif salah satunya dapat mendatangkan devisa bagi negara.Usaha pemanfaatan panas bumi pada dasarnya mencangkup 3 upaya yaitu pencarian (eksplorasi), penggalian (eksploitasi), dan pengolahan. Sehingga dalam mencari potensi adanya panas bumi tidak boleh dilakukan disembarang tempat.

Dalam pengelolaan pemanfaatan panas bumi dapat dikelola oleh pihak pihak tertentu. Pihak tersebut salah satunya ialah badan korporasi. Badan korporasi inilah yang memiliki peran dalam pengelolaan dan pemanfataan panas bumi sebagai energi yang terbarukan dan diharapkan menjadi bagian dari penopang energi nasional. Salah satu impian masyarakat dalam menempati suatu pemukiman yaitu dengan terciptanya lingkungan yang bersih. Lingkungan hidup menurut UndangUndang Nomor 32 Tahun 2009 tentang Perlindungan Lingkungan Hidup Pasal 1 angka 1 yaitu kesatuan ruang dari semua benda, daya, keadaan, dan makhluk hidup, termasuk manusia dan perilakunya yang berpengaruh terhadap alam itu sendiri. Lingkungan dan pembangunan memiliki beberapa perbedaan dilihat dari sudut pandangnya. Pembangunan dapat menimbulkan kerusakan lingkungan yang menyebabkan pencemaran akibat penggunaan sumber daya alam yang berlebihan. Pencemaran lingkungan dapat terjadi karena masalah lingkungan yang disebabkan oleh pembangunan. Dampak dari pembangunan dan aktivitas tersebut dapat dirasakan oleh masyarakat sebagai masalah dini yang harus ditangani sejak dini. Pencemaran tersebut terdiri dari atas pencemaran udara, pencemaran air, pencemaran dan perusakan tanah serta pencemaran laut.

Untuk melakukan pembangunan pembangkit listrik tenaga panas bumi harus dilakukan dengan mengebor tanah didaerah yang memiliki potensi panas bumi yang bertujuan untuk membuat lubang gas panas yang dapat dimanfaatkan untuk memanaskan ketel uap (boiler) sehingga uapnya dapat menggerakan turbin uap yang tersambung ke generator. ${ }^{6}$ Proses eksplorasi menurut pasal 1 angka 9 
Undang-Undang Nomor 21 Tahun 2014 tentang Panas Bumi yaitu proses kegiatan yang meliputi penyelidikan geologi, geofisika, geokimia, pengeboran ujian serta pengeboran sumur eksplorasi yang bertujuan untuk memperoleh informasi kondisi geologi bawah permukaan guna menemukan dan mendapatkan perkiraan cadangan panas bumi. Dampak lingkungan dari aktivitas eksplorasi panas bumi ini dapat dikaitkan dengan isu pencemaran air yang berupa air sungai disekitar pembangkit listrik tenaga panas bumi yang berubah menjadi keruh akibat dari pengeprasan bukit yang menyisakan sedimen tanah yang akhirnya hanyut ke mata air dan sungai. Proses eksplorasi tersebut dilakukan oleh badan usaha yang berperan sebagai pengelola dari pembangkit listrik tenaga panas bumi tersebut. Kegiatan eksplorasi pada pembangkit listrik tenaga panas bumi tersebut yang tidak memperhatikan aspek kelestarian lingkungan akan menimbulkan dampak buruk bagi lingkungan yang dapat berpengaruh terhadap kehidupan masyarakat. ${ }^{7}$

\section{Metode Penelitian}

Metode yang digunakan dalam penelitian ini adalah penelitian hukum yang dilakukan dengan cara meneliti bahan-bahan pustaka atau data-data sekunder belaka. Penelitian ini bersifat Yuridis Normatif, oleh karena didasarkan pada metode, sistematika dan pemikiran tertentu dengan tujuan mempelajari suatu atau beberapa gejala hukum tertentu dan menganalisisnya.

\section{Korporasi}

Secara etimologi kata korporasi menurut bahasa Belanda yaitu corproratie, bahasa Inggris yaitu corporation, bahasa Jerman corporation berasal dari kata corporatio dalam bahasa latin. Sedangkan dalam bahasa Indonesia Corporare berasal dari kata "corpus" yang berarti memberikan badan atau membadankan. Corporation merupakan hasil dari pekerjaan membadankan dengan kata lain badan

\footnotetext{
7 Trianto W.M dan Sulistyono, 'Sumber Limbah dan Potensi Pencemaran Penggunaan Sumber Daya Alam (Geothermal) Pada Industri Pembangkit Listrik Tenaga Panas Bumi (PLTP)’ (2019) Vol 9 Swara Patra.[54].
} 
yang dijadikan orang, badan yang diperoleh dengan perbuatan manusia sebagai lawan terhadap badan manusia yang terjadi menurut alam. ${ }^{8}$

Korporasi secara terminologi memiliki pengertian yang telah dirumuskan oleh beberapa ahli hukum. Menurut Subekti dan Tjitrosudibo, corporatie atau korporasi adalah suatu perseorangan yang merupakan badan hukum. ${ }^{9}$ Sedangkan, menurut Yan Pramadya Puspa, korporasi yaitu suatu perseorangan yang merupakan badam hukum. Dalam hal ini korporasi adalah suatu perkumpulan atau organisasi yang oleh hukum diperlukan seperti manusia (persona) sebagai pemilik hak dan kewajiban memiliki hak menggugat ataupun digugat dimuka pengadilan. ${ }^{10}$ Korporasi merupakan subjek hukum (recht persoon) yang merupakan bentuk artificial person dari seorang manusia yang dapat memiliki hak dan kewajiban hukum. ${ }^{11}$

Sebagai subyek hukum, korporasi tidak hanya menjalankan kegiatannya sejalan dengan prinsip ekonomi yaitu mencari keuntungan yang sebesar-besarnya melainkan juga memiliki kewajiban untuk mematuhi peraturan hukum di bidang ekonomi yang digunakan pemerintah untuk mewujudkan kesejahteraan masyarakat dan keadilan sosial $^{12}$. Didalam proses modernisasi atau pembangunan, korporasi diharapkan memiliki beberapa peranan diantaranya memperhatikan dan membina kelestarian kemampuan sumber daya alam dan lingkungan hidup ${ }^{13}$. Suatu korporasi yang tidak mempunyai visi ekologis dan rencana kerja yang signifikan pada aspek pengelolaan lingkungan di internal perusahaannya dapat diduga jika mereka tidak termasuk "green company" secara kategoris tidak pro-lingkungan. ${ }^{14}$ Terjadinya pencemaran dan/atau kerusakan lingkungan sebagian besar dilakukan dalam konteks menjalankan suatu usaha ekonomi dan sering juga merupakan sikap penguasa ataupun pengusaha

8 Muladi, Dwidja Priyanto, Pertanggungjawaban Pidana Korporasi (Kencana 2010).[23].

9 Chaidir Ali, Badan Hukum (Alumni 1991).[14].

${ }_{10}$ Barda Nawawi Arief, Bunga Rampai Hukum Pidana (Citra Aditya Bakti 1996). [12].

${ }^{11}$ Albert Aries, Pertanggungjawaban Pengurus Dalam Tindak Pidana Korporasi, $<\mathrm{https}: / /$ www.hukumonline.com/klinik/detail/lt5a5ecc109ea26/pertanggungjawaban-pengurus-dalam-tindak-pidana-korporasi/>. diakses pada 8 Agustus 2020, pukul 00.30.

${ }_{12}$ Sonny Keraf.A, Etika Bisnis Tuntutan dan Relevansinya (Penerbit Kanisius 1998).[23].

${ }_{13}$ Hamzah Hatrik, Asas Pertanggungjawaban Korporasi Dalam Hukum Pidana Indonesia (Strict Liability dan Vicoatius Liability) (Raja Grafindo Persada 1996).[24]. 2012).[38].

14 Suparto Wijoyo, Hukum Lingkungan di antara Para Pemalas (Airlangga University Press 
yang tidak menjalankan atau melalaikan kewajiban-kewajibannya dalam pengelolaan lingkungan hidup ${ }^{15}$. Pencemaran dan/atau kerusakan lingkungan akan terus meningkat seiring dengan meningkatnya kegiatan industri atau sejenisnya sehingga lingkungan hidup perlu mendapatkan perlindungan hukum. ${ }^{16}$

\section{Tanggung Jawab}

Tanggung jawab menurut kamus hukum adalah suatu keharusan bagi seseorang untuk melaksanakan apa yang telah diwajibkan kepadanya. ${ }^{17}$ Terdapat dua istilah dalam kamus hukum yang merujuk pada pertanggungjawaban yaitu liability dan responsbility. Liability adalah istilah hukum yang memiliki arti luas yang mengandung hampir semua karakter risiko atau tanggung jawab, yang pasti, yang bergantung, atau yang mungkin meliputi semua karakter hak serta kewajiban secara potensial seperti kerugian, ancaman, kejahatan, biaya, atau kondisi yang memunculkan tugas untuk melaksanakan undang-undang. Responsibility merupakan hal yang bisa dipertanggungjawabkan atas suatu kewajiban dan termasuk keputusan, keterampilan, kemampuan, dan kecakapan yang merupakan kewajiban bertanggung jawab atas undang-undang yang dilaksanakan. Liability merujuk pada pertanggungjawaban hukum yakni tanggung gugat akibat kesalahan yang diakibatkan oleh tindakan subjek hukum. Sedangkan, responsibility merujuk pada pertanggungjawaban politik. ${ }^{18}$

Tanggung jawab menurut Purbacaraka yaitu tanggung jawab hukum lahir atas penggunakan fasilitas dalam penerapan kemampuan tiap orang untuk menggunakan hak dan melaksanakan kewajibannya. Lebih detail dijelaskan bahwa setiap pelaksanaan kewajiban dan setiap penggunaan hak baik yang dilakukan secara memadai maupun tidak memadai pada dasarnya tetap harus diiringi dengan pertanggungjawaban, begitu juga dengan pelaksanaan kekuasaannya. ${ }^{19}$

\footnotetext{
${ }_{15}$ Wahono Baoed, Penegakan Hukum Lingkungan Melalui Ketentuan-Ketentuan Hukum Pidana (Mahkamah Agung RI 1996).[42].

${ }^{16}$ Koesnadi Hardjosoemantri, Hukum Tata Lingkungan (Gajahmada University Press 2002). [95].

${ }^{17}$ Andi Hamzah, Kamus Hukum (Ghalia Indonesia 2005).[47].

${ }_{18}$ Ridwan H.R, Hukum Administrasi Negara (Raja Grafindo Persada 2013).[35].

19 Purbacaraka, Perihal Kaedah Hukum (Citra Aditya 2010).[37].
} 


\section{Pertanggungjawaban Korporasi Sebagai Pengelola Pengelola Pembangkit}

\section{Listrik Tenaga Panas Bumi Atas Dampak Pencemaran Lingkungan Yang} Timbul Dari Aktivitas Eksplorasi

Bentuk pertanggungjawaban yang dapat diberikan oleh badan korporasi yang mengelola Pembangkit Listrik Tenaga Panas Bumi yang dalam kegiatan eksplorasi yang dilakukannya telah menyebabkan pencemaran lingkungan dan berdampak kepada masyarakat yang ada disekitar Pembangkit Listrik Tenaga Panas Bumi yaitu dapat berupa pertanggung jawaban perdata berupa ganti rugi kepada masyarakat yang dirugikan, pertanggung jawaban pidana berupa penutupan kegiatan usaha, perampasan keuntungan yang diperoleh dari tindak pidana serta denda bagi pelaku yang melakukan tindak pidana. Pertanggung jawaban pidana terhadap korporasi diatur dalam pasal 116 sampai pasal 120 UUPPLH. Pertanggung jawaban administrasi yang diatur didalam pasal 76 sampai pasal 79 UUPPLH berupa teguran tertulis, paksaan pemerintah, pembekuan dan pencabutan izin lingkungan. Korporasi yang memiliki pengusahaan panas bumi dapat dikenakan sanksi administrasi berupa teguran tertulis, penghentian kegiatan ekplorasi, eksploitasi dan pemanfaatan serta pencabutan izin menurut pasal 56 UU Panas Bumi. Korporasi dalam pengusahaan panas bumi memiliki kewajiban yang harus dipenuhi yaitu tanggung jawab sosial dan lingkungan. Korporasi sebagai pemegang izin panas bumi wajib melakukan pengendalian pencemaran dan/atau kerusakan lingkungan hidup yang meliputi kegiatan pencegahan, penanggulangan, dan pemulihan fungsi lingkungan hidup berdasarkan pasal 52 ayat (1) huruf b UU Panas Bumi. Tanggung jawab korporasi kepada para pihak yang terdampak pencemaran dapat berupa:

a. Pengelola Pembangkit Listrik Tenaga Panas Bumi harus membayarkan ganti rugi kepada masyarakat yang terkena dampak pencemaran lingkungan akibat dari proses eksplorasi;

b. Pengelola Pembangkit Listrik Tenaga Panas bumi harus melakukan tindakan pemulihan yang diakibatkan dari pencemaran yang berasal dari proses eksplorasi;

c. Pengelola Pembangkit Listrik Tenaga Panas Bumi harus memberikan jaminan agar tidak terjadi pencemaran lingkungan akibat dari proses eksplorasi;

d. Pengelola Pembangkit Listrik Tenaga Panas Bumi harus melakukan tindakan yang bertujuan untuk mencegah terjadinya dampak negatif terhadap lingkungan sekitar area kegiatan Pembangkit Listrik Tenaga Panas Bumi. 
Apabila terjadi pelanggaran pencemaran dan/atau kerusakan lingkungan yang telah diputuskan oleh pengadilan maka penggolongan jenis kerugian akibat pencemaran dan/atau perusakan lingkungan hidup berdasarkan Peraturan Menteri Lingkungan Hidup Republik Indonesia Nomor 7 Tahun 2014 Tentang Kerugian Lingkungan Hidup Akibat Pencemaran Dan/Atau Kerusakan Lingkungan Hidup, korporasi sebagai pengelola diwajibkan untuk membayar biaya penanggulangan, biaya pemulihan, biaya kerugian ekosistem serta biaya kerugian masyarakat akibat pencemaran dan/atau kerusakan lingkungan yang telah ditimbulkannya.

\section{Perlindungan Hukum}

Perlindungan hukum terbagi menjadi dua suku kata yaitu perlindungan dan hukum yang memiliki makna perlindungan menurut hukum serta undang-undang yang berlaku. Saat subyek hukum bersinggungan dengan peristiwa hukum maka subyek hukum dapat diberikan perlindungan hukum yang dapat digunakan sebagai sarana mewujudkan dan mempertahankan keadilan. Perlindungan hukum diberikan kepada masyarakat sebagai wujud pengayoman kepada hak asasi manusia yang mendapat kerugian dari orang lain sehingga masyarakat dapat menikmati semua hak-hak yang diberikan oleh hukum. Perlindungan hukum yaitu berbagai upaya hukum yang diberikan kepada penegak hukum dengan tujuan memberikan rasa aman secara fisik maupun pikiran dari berbagai ancaman serta gangguan dari berbagai pihak. ${ }^{20}$

Kegunaan dari perlindungan hukum yaitu untuk memberikan jaminan kepada masyarakat dalam mendapatkan perlindungan menurut peraturan perundangundangan yang berlaku. Philipus M.Hadjon berpendapat bahwa perlindungan hukum bagi rakyat mencangkup dua hal, yaitu: ${ }^{21}$

a. Perlindungan hukum preventif

Pada perlindungan hukum preventif ini, subyek hukum diberikan kesempatan untuk mengajukan keberatan atau pendapatnya sebelum suatu keputusan pe-

\footnotetext{
${ }^{20}$ Satjipto Raharjo, Ilmu Hukum (Citra Aditya 2014).[74].

${ }^{21}$ Philipus M.Hadjon, Perlindungan Hukum Bagi Rakyat Indonesia (Bina Ilmu 1987).[28].
} 
merintah mendapat bentuk yang definitif. Tujuan dari perlindungan hukum preventif adalah untuk mencegah terjadinya sengketa.

b. Perlindungan hukum represif

Perlindungan hukum represif memiliki tujuan untuk menyelesaikan sengketa. Prinsip perlindungan hukum terhadap tindakan pemerintah bersumber dari konsep tentang pengakuan dan perlindungan terhadap hak-hak asasi manusia sebab lahirnya konsep-konsep tentang pengakuan dan perlindungan terhadap hak-hak asasi manusia diarahkan kepada pembatasan-pembatasan serta peletakan kewajiban masyarakat dan pemerintah. Pengakuan dan perlindungan terhadap hak-hak asasi manusia mendapat tempat utama dan dapat dikaitkan dengan tujuan negara hukum.

Penegakan hukum yang bersifat preventif memiliki arti bahwa pengawasan secara aktif dilakukan terhadap kepatuhan kepada peraturan tanpa kejadian langsung yang menyangkut peristiwa konkrit yang mengakibatkan sangkaan jika hukum telah dilanggar. ${ }^{22}$ Penyuluhan, pemantauan, dan penggunaan kewenangan yang sifatnya pengawasan merupakan instrumen bagi penegakan hukum preventif sehingga penegak hukum yang utama adalah pejabat/aparat pemerintah yang berwenang memberi izin dan mencegah terjadinya pencemaran dan/atau kerusakan lingkungan. ${ }^{23}$ Penegakan hukum represif dilakukan dalam hal perbuatan yang melanggar peraturan dengan tujuan untuk mengakhiri secara langsung perbuatan terlarang. ${ }^{24}$

\section{Hak Atas Perlindungan Hukum}

Hak atas perlindungan hukum memiliki makna yang sangat penting dalam upaya untuk memenuhi hak-hak lain dalam pengelolaan lingkungan hidup. Berdasarkan Pasal 66 UUPPLH menyebutkan bahwa "Setiap orang yang memperjuangkan hak atas lingkungan hidup yang baik dan sehat tidak dapat dituntut

22 Siti Sundari Rangkuti, Hukum Lingkungan Dan Kebijaksanaan Lingkungan Nasional (Airlangga University Press 2015).[222].

23 ibid.

24 ibid. 
secara pidana maupun digugat secara perdata". Maksud dalam Pasal 66 UUPPLH ini yaitu untuk melindungi korban dan/atau pelapor yang menempuh jalur hukum akibat pencemaran atau perusakan lingkungan hidup. Menurut penjelasan Pasal 66 UUPPLH ini perlindungan ditujukan guna mencegah tindakan pembalasan dari terlapor melalui pemidanaan dan/atau gugatan perdata dengan tetap memperhatikan kemandirian pengadilan. Dengan adanya ketentuan tersebut, diharapkan masyarakat yang menderita kerugian akibat pencemaran atau perusakan lingkungan hidup dapat menuntut perbaikan tanpa dibayangi rasa takut. Jaminan perlindungan hukum dalam Pasal 66 UUPPLH tersebut harus dipahami serta dimaknai sehingga dalam melakukan tuntutan harus dilakukan sesuai dengan prosedur hukum dan tata nilai yang berlaku dalam masyarakat, tidak dilakukan dengan melakukan pelanggaran hukum serta tindakan tercela lainnya. Walaupun terdapat jaminan perlindunga hukum, dalam melakukan tuntutan tetap harus mengikuti ketentuan hukum dan nilai-nilai kepatutan yang ada didalam masyarakat. ${ }^{25}$ Berdasarkan Pasal $28 \mathrm{H}$ ayat (1) UUD 1945 dan Pasal 28 Piagam Hak Asasi Manusia yang ada didalam Ketetapan MPR-RI No. XVII/MPR/1998 tentang Hak Asasi Manusia menyebutkan bahwa hak atas lingkungan hidup yang baik dan sehat merupakan hak fundamentalkonstitusional. Pasal 28H ayat (1) UUD 1945 dan Pasal 28 Piagam Hak Asasi Manusia mempunyai implikasi hukum sebagai dasar hukum gugatan lingkungan yang substansif bagi pemenuhan fungsi hak perseorangan, baik melalui forum dipengadilan maupun di luar pengadilan.

Berdasarkan pasal 65 ayat (2) hurufd UU Panas Bumi, dalam penyelenggaraan usaha pemanfaatan panas bumi, masyarakat berhak untuk mengajukan gugatan akibat kegiatan pengusahaan panas bumi yang menyalahi ketentuan. Selain itu dalam pasal 65 UU Panas Bumi, masyarakat memiliki hak untuk:

a. Memperoleh informasi berkaitan dengan pengusahaan Panas Bumi melalui Pemerintah atau Pemda sesuai dengan kewenangannya;

b. Mendapat manfaat dari kegiatan pengusahaan panas bumi melalui kewajiban perusahaan untuk memenuhi tanggung jawab sosial perusahaan dan/atau 
pengembangan masyarakat disekitar;

c. Mendapat ganti rugi yang layak akibat kesalahan dalam kegiatan pengusahaan panas bumi sesuai dengan ketentuan perundang-undangan;

d. Dapat mengajukan gugatan kepada pengadilan terhadap kerugian akibat kegiatan pengusahaan Panas Bumi yang menyalahi ketentuan.

\section{Perlindungan Hukum Bagi Masyarakat Yang Terkena Dampak Pencemaran} Akibat Aktivitas Eksplorasi Pembangkit Listrik Tenaga Panas Bumi

Dampak yang ditimbulkan dari pencemaran lingkungan akibat aktifitas eksplorasi yang dilakukan oleh badan korporasi selaku pengelola Pembangkit Listrik Tenaga Panas Bumi yaitu dampak ekonomi, dampak sosial, dan dampak lingkungan yang berpengaruh terhadap masyarakat disekitarnya. Diperlukan perlindungan hukum bagi masyarakat akibat dari pencemaran yang dilakukan oleh korporasi selaku pengelola panas bumi. Bentuk perlindungan hukum yang dimiliki oleh masyarakat yaitu masyarakat dapat mengajukan gugatan akibat pengusahaan panas bumi yang melanggar ketentuan yang dilakukan oleh korporasi. Gugatan tersebut dapat berupa gugatan di pengadilan dan diluar pengadilan. Masyarakat yang menderita kerugian akibat pencemaran dari aktivitas eksplorasi panas bumi dapat mengajukan gugatan perwakilan kelompok untuk kepentingannya sendiri dan/atau kepentingan masyarakat apabila mengalami kerugian akibat pencemaran lingkungan. Gugatan dapat dilakukan jika memenuhi syarat yaitu adanya kesamaan peristiwa, dasar hukum serta jenis tuntutan diantara wakil kelompok dan anggota kelompoknya. Berdasarkan pasal 65 ayat (2) UU Panas Bumi, masyarakat berhak untuk memperoleh informasi yang berkaitan dengan pengusahaan panas bumi melalui pemerintah atau pemda sesuai dengan kewenangannya, masyarakat berhak memperoleh manfaat dari kegiataan pengusahaan panas bumi melalui kewajiban korporasi untuk memenuhi tanggung jawab sosial perusahaan, masyarakat berhak mendapat ganti rugi yang layak akibat kesalahan dalam kegiatan pengusahaan panas bumi yang dilakukan oleh korporasi, masyarakat berhak untuk mengajukan gugatan kepada pengadilan terhadap kerugian akibat kegiatan pengusahaan panas bumi yang menyalahi ketentuan. 
Dampak yang ditimbulkan dari pencemaran lingkungan akibat aktivitas eksplorasi yang dilakukan oleh badan korporasi selaku pengelola Pembangkit Listrik Tenaga Panas Bumi yaitu dampak ekonomi, dampak sosial, dan dampak lingkungan yang berpengaruh terhadap masyarakat disekitarnya. Diperlukan perlindungan hukum bagi masyarakat akibat dari pencemaran yang dilakukan oleh korporasi selaku pengelola panas bumi. Bentuk perlindungan hukum yang dimiliki oleh masyarakat yaitu masyarakat dapat mengajukan gugatan akibat pengusahaan panas bumi yang melanggar ketentuan yang dilakukan oleh korporasi. Gugatan tersebut dapat berupa gugatan di pengadilan dan diluar pengadilan. Masyarakat yang menderita kerugian akibat pencemaran dari aktivitas eksplorasi panas bumi dapat mengajukan gugatan perwakilan kelompok untuk kepentingannya sendiri dan/atau kepentingan masyarakat apabila mengalami kerugian akibat pencemaran lingkungan. Gugatan dapat dilakukan jika memenuhi syarat yaitu adanya kesamaan peristiwa, dasar hukum serta jenis tuntutan diantara wakil kelompok dan anggota kelompoknya. Berdasarkan pasal 65 ayat (2) UU Panas Bumi, masyarakat berhak untuk memperoleh informasi yang berkaitan dengan pengusahaan panas bumi melalui pemerintah atau pemda sesuai dengan kewenangannya, masyarakat berhak memperoleh manfaat dari kegiataan pengusahaan panas bumi melalui kewajiban korporasi untuk memenuhi tanggung jawab sosial perusahaan, masyarakat berhak mendapat ganti rugi yang layak akibat kesalahan dalam kegiatan pengusahaan panas bumi yang dilakukan oleh korporasi, masyarakat berhak untuk mengajukan gugatan kepada pengadilan terhadap kerugian akibat kegiatan pengusahaan panas bumi yang menyalahi ketentuan.

\section{Kesimpulan}

Korporasi sebagai pemegang izin panas bumi wajib melakukan pengendalian pencemaran dan/atau kerusakan lingkungan hidup yang meliputi kegiatan pencegahan, penanggulangan, dan pemulihan fungsi lingkungan hidup. Apabila terdapat putusan dari pengadilan, korporasi sebagai pengelola PLTP diwajibkan untuk membayar biaya penanggulangan, biaya pemulihan, biaya kerugian ekosistem 
serta biaya kerugian masyarakat akibat pencemaran dan/atau kerusakan lingkungan yang telah ditimbulkannya.

Bentuk perlindungan hukum yang dimiliki oleh masyarakat yaitu masyarakat berhak untuk memperoleh informasi yang berkaitan dengan pengusahaan panas bumi melalui pemerintah atau pemda sesuai dengan kewenangannya, masyarakat berhak memperoleh manfaat dari kegiataan pengusahaan panas bumi melalui kewajiban korporasi untuk memenuhi tanggung jawab sosial perusahaan, masyarakat berhak mendapat ganti rugi yang layak akibat kesalahan dalam kegiatan pengusahaan panas bumi yang dilakukan oleh korporasi, masyarakat berhak untuk mengajukan gugatan kepada pengadilan terhadap kerugian akibat kegiatan pengusahaan panas bumi yang menyalahi ketentuan.

Seharusnya pertanggung jawaban pidana korporasi juga diatur didalam UU Panas Bumi yang mengatur pengusahaan panas bumi secara lebih khusus selain itu korporasi sebagai pengelola PLTP juga harus menyediakan ruang aspirasi bagi masyarakat. Seyogyanya organisasi lingkungan hidup pro aktif sehingga masyarakat dapat lebih peduli terhadap lingkungan hidup.

\section{Daftar Bacaan}

\section{Buku}

A.M Wahid Yunus, Pengantar Hukum Lingkungan (Prenadamedia Group).

Abdul Kadir, Energi:Sumber Daya, Inovasi, Tenaga Listrik, dan Potensi Ekonomi (Penerbit Universitas Indonesia).

Adrian Sutedi, Hukum Pertambangan (Sinar Grafika).

Andi Hamzah, Kamus Hukum (Ghalia Indonesia).

Barda Nawawi Arief, Bunga Rampai Hukum Pidana (Citra Aditya Bakti).

Chaidir Ali, Badan Hukum (Alumni).

H.Salin HS, Hukum Pertambangan di Indonesia (Raja Grafindo Persada).

Hamzah Hatrik, Asas Pertanggungjawaban Korporasi Dalam Hukum Pidana 
Indonesia (Strict Liability dan Vicoatius Liability) (Raja Grafindo Persada).

Koesnadi Hardjosoemantri, Hukum Tata Lingkungan (Gajahmada University Press 2002).

Muladi, Dwidja Priyanto, Pertanggungjawaban Pidana Korporasi (Kencana).

Nandang Sudrajat, Teori dan Praktik Pertambangan Indonesia (Pustaka Yustisia).

Philipus M.Hadjon, Perlindungan Hukum Bagi Rakyat Indonesia (Bina Ilmu).

Purbacaraka, Perihal Kaedah Hukum (Citra Aditya).

Ridwan H.R, Hukum Administrasi Negara (Raja Grafindo Persada).

Satjipto Raharjo, Ilmu Hukum (Citra Aditya).

Siti Sundari Rangkuti, Hukum Lingkungan Dan Kebijaksanaan Lingkungan Nasional (Airlangga University Press).

Sonny Keraf.A, Etika Bisnis Tuntutan dan Relevansinya (Penerbit Kanisius).

Suparto Wijoyo, Hukum Lingkungan di antara Para Pemalas (Airlangga University Press).

Wahono Baoed, Penegakan Hukum Lingkungan Melalui Ketentuan-Ketentuan Hukum Pidana (Mahkamah Agung RI).

\section{Jurnal}

M Hafiz Alfath, 'Listrik Dari Panas Bumi' (2010) Vol. 40 No. 3 Jurnal Hukum dan Pembangunan Universitas Indonesia.

Trianto W.M dan Sulistyono, 'Sumber Limbah dan Potensi Pencemaran Penggunaan Sumber Daya Alam (Geothermal) Pada Industri Pembangkit Listrik Tenaga Panas Bumi (PLTP)' (2019) Vol 9 Swara Patra.

\section{Laman}

Albert Aries, 'Pertanggungjawaban Pengurus Dalam Tindak Pidana Korporasi', $<$ https://www.hukumonline.com/klinik/detail/lt5a5ecc109ea26/ pertanggungjawaban-pengurus-dalam-tindak-pidana-korporasi/>. diakses pada 8 Agustus 2020, pukul 00.30. 


\section{Perundang-undangan}

Undang-Undang Dasar Negara Republik Indonesia Tahun 1945.

Undang-Undang Nomor 5 Tahun 1960 tentang Peraturan Dasar Pokok-Pokok Agraria (Lembaran Negara Republik Indonesia Tahun 1960 Nomor 104, Tambahan Lembaran Negara Republik Indonesia Nomor 2043).

Undang-Undang Nomor 32 Tahun 2009 tentang Perlindungan dan Pengelolaan Lingkungan Hidup (Lembaran Negara Republik Indonesia Tahun 2009, Nomor 140).

Undang-Undang Nomor 21 Tahun 2014 tentang Panas Bumi (Lembaran Negara Republik Indonesia Tahun 2014, Nomor 217).

Peraturan Pemerintah Nomor 27 Tahun 2012 tentang Izin Lingkungan (Lembaran Negara Republik Indonesia Nomor 48).

Peraturan Menteri Lingkungan Hidup Nomor 7 Tahun 2014 tentang Kerugian Lingkungan Hidup Akibat Pencemaran Dan/Atau Kerusakan Lingkungan Hidup (Lembaran Negara Republik Indonesia Nomor 1726).

Peraturan Pemerintah Nomor 7 Tahun 2017 tentang Panas Bumi Untuk Pemanfaatan Secara Tidak Langsung (Lembaran Negara Republik Indonesia Nomor 6023). 